\title{
CORRUPTION WITHIN SECURITY FORCES
}

\author{
W. G. Brînză
}

\author{
William Gabriel Brînză \\ Faculty of Law, Law Department \\ "Dimitrie Cantemir" Christian University, Bucharest, Romania \\ *Correspondence: William Gabriel Brînză, Palace of Parliament, 2-4 Izvor St., Bucharest, \\ Romania \\ E-mail:william@williameuropa.eu
}

\begin{abstract}
These criminal organizations aim at corrupting officials willing to influence public politics and to protect different illegal activities, in exchange for some undeserved advantages. Once inside in this game, the official will bend to any pressure coming from the criminal group, and the group will have no difficulties in finding more and more convenient ways to develop illicit activities.
\end{abstract}

Keywords: corruption, forces crime, national security the impact

\section{Introduction}

In September 1999, took place the first conference which dealt with the impact of organized crime against the national security of the states. Follow-up this meeting, many representatives of the participating countries and present organizations, being aware of the ampleness of the consequences of corruption even in the most secure institutions of the states, solicited the forming of a new conference on the same topic. Their solicitation was taken in consideration, and, on 14-18 May 2001, the George C. Marshall Center of Security Studies hosted an international conference on the topic "Corruption within Security Forces: A Threat to National Security" sponsored by the Federal Bureau of Investigations of the United States with the collaboration of Bundeskriminalamt from Germany. At this last reunion, at which participated over 40 states from Europe, Asia, America, the accent was put on corruption at the level of the government officials and security forces, on the consequences and the possibilities to confute it. The participants discussed the situation of the countries in transition which confront with numerous problems with the implementation of the anti-corruption fighting strategies.

During the discussions, an idea was launched, according to which the main cause of corruption increase is global development and organized crime at an international level, offers opportunities for transport over the border including drug traffic, human traffic, gun running. Lately, the main target of criminal group is represented by Security Forces which refer to all the institutions of the state which serve to apply the law, to the control at the national border, including the border police, immigration agencies, military services, custom's units, local and national police. The Security Forces have become the target of corruption because they control the force monopoly, they can be used as instruments by the criminal groups, have access to munitions and secret information and can facilitate the accomplishment of activities which are against the law.

The Security Forces staff has proven to be easy to corrupt the reasons invoked are the poor compensations, the lack of fortitude accompanied by the small possibility to be "exposed". 
The most suitable means to annihilate corruption is considered to be electronic surveillance, used in undercover operations, advanced procedures of investigation, witness immunity and protection. Furthermore, the civil control of the Security Forces is essential in the preventing activity of corruption; in this direction, the vice-agents must appoint the anticorruption boards which must modify the legislation and to adapt to its conditions, to perform investigations within the institutions, to secure the necessary means to recruit personnel, to elaborate codes of behavior, to monitor the conflicts of interest and to allow the access to information of the media and to some non-governmental organizations.

The accent was put on the importance of recruiting among population honest people, with self-control, fortitude, and with the spirit of sacrifice. Like in every other strategy, the society has a very important part; in order to win people's confidence the administration of the state must bear in mind the promotion of a transparent politics by ensuring free access to information, the cooperation with the media and with non-governmental organizations, which can be used by criminal organizations in concealing the truth.

In his intervention, Michael De Foe, F.B.I.'s Deputy Director, declared that the common factor of all scandals within the Security Forces is the lack of supervisors and the negligence of the administrators, which become most of the times accomplices in corruption cases. The instauration of severe measures of discipline, associated with intolerance of the leaders towards less important acts could intimidate personnel and determine it to avoid any act opposed to his attributions.

International cooperation in this area is an objective which must be taken into consideration, following the appraisal and interpretation of all the aspects of corruption and making sure of the collaboration of investigation units from different states.

The most affected states within the Security Forces by the corruption phenomenon are the once being in a transition period. The Global Assembly of the Central and Eastern European countries came to the conclusion that the worst enemy of evolution or the road to democracy is corruption, fact proven after an action attended in Albania, Bulgaria, Croatia, Macedonia, Romania and Serbia.

Corruption is defined as: "office or the public office abuse for personal benefit". During the same conference an idea was issued according to which corruption is the perfect way for the organized crime to manifest its power, as long as there is organized crime there probably exists corruption and the need for corruption.

Both discovering and investigating corruption cases is difficult to accomplish for at least five reasons:

- Corruption infractions are almost always committed undercover;

- Corruption involves a relative small number of participants;

- Many times, the institutions themselves manage the application of corrupted laws;

- Corruption has the potential to act for long periods of time;

- Corruption involves distraction this is why, every time a crime is discovered measures are taken to lade the process of gathering evidence and of finding out the truth.

Due to the penetration of corruption in all social layers, action must be taken against this phenomenon which threatens the national and economical security of one state, regional and democratic stability, isolating the corrupt country both in a diplomatic and economic matter.

For the elaboration of an anti-corruption strategy it was suggested the following of a few preceding steps and taking in consideration a few ideas:

- As for the adopted laws, they must have been applied by several other countries, with the same purpose, having positive results, but they also must be appropriate with the situation of the country in discussion, with the national interests, and it is mandatory to be applied;

- $\quad$ The second step is the elaboration of a definition of corruption, which must contain all its essential aspects, to incriminate the conflict of interests, the defining of 
the term public servant, to incriminate the illegal usage of government resources, money laundering and bribery.

The fight against corruption becomes more efficient when it is applied on a sector; the steps cited previously are generally valid independent from the domain we are taking in consideration. For the annihilation of corruption within Security Forces, some directions were proposed:

- Defining "organized crime";

- The elaboration of a legal case referring to the Security Forces;

- The investigation of corrupt infractions must be made by the permanent departments of investigation, which must be independent and autonomous;

- To appoint the procedures which must be followed during the investigation of corruption cases;

- The departments of investigation must have the necessary tool in order to discover and investigate infractions;

foresight;

The staff within Security Forces must report any contravention of the legal

- The use of various methods to finish the investigations: electronic surveillance, interrogations, accounting auditing, undercover operations, the use of informers, assuring the protection of the witnesses, negotiation tactics of the punishment.

\section{Conclusions}

Some of the most important objectives of the meeting were:

- The evaluation of the threat corruption represents for the development processes and democratic institutions, and on the impact corruption might have on the Security Forces, on security, and on national stability.

- Establishing measures which must be taken to identify and annihilate corruption within Security Forces.

To elaborate proposals which will be implemented local or transnational, in order to annihilate corruption within Security Forces.

The proposed measures have mainly addressed to the influencers factors at the governmental level. The outcome of the conference were satisfactory, most of the parliamentarians present managing to create plans to annihilate corruption, follow-up ideas of other states with experience in this domain.

Trying to find an explanation to the corruption problem which entered within Security Forces, some experts were asked for their opinion, who declared that through corruption, the criminal organizations manage to carry out their influence in an efficient and cheap manner. These criminal organizations aim at corrupting officials willing to influence public politics and to protect different illegal activities, in exchange for some undeserved advantages. Once inside in this game, the official will bend to any pressure coming from the criminal group, and the group will have no difficulties in finding more and more convenient ways to develop illicit activities.

\section{Bibliography}

Dumitru Mazilu - "Preventing and relucting corruption" - major undiscriminating of the development of commercial trades based on the fundamental principles and specifications of the international commerce", The Commercial Law no. 1/ 2002;

A Report of the George C. Marshall European Center of Security Studies Conference on Corruption Within Security Forces - A Threat to National Security, May 14-18, 2001, Garmish-Parten Kirchen, Germany;

Samuel P. Huntington - "Political Order in Changing Societes", Yale University Press, New Haven and London, 1968. 